\title{
Inter-regional variation on leaf surface defenses in native and non-native Centaurea solstitialis plants
}

\author{
Gastón J. Sotes a, b, *, Lohengrin A. Cavieres ${ }^{\text {a, b }}{ }^{\text {, Daniel Montesinos }}{ }^{\text {c }}$, \\ António Xavier Pereira Coutinho ${ }^{c}$, Walter José Peláez ${ }^{\mathrm{d}}$, Susana M.M. Lopes ${ }^{\mathrm{e}}$, \\ Teresa M.V.D. Pinho e Melo ${ }^{\text {e }}$ \\ a Departamento de Botánica, Facultad de Ciencias Naturales y Oceanográficas, Universidad de Concepción, Víctor Lamas 1290, \\ P.O. Box 160 C, Concepción, Chile \\ ${ }^{\mathrm{b}}$ Instituto de Ecología y Biodiversidad (IEB), Universidad de Chile, P.O. Box 653, Santiago, Chile \\ ${ }^{\mathrm{c}}$ Center for Functional Ecology, Department of Life Sciences, University of Coimbra, Calçada Martim de Freitas, $3000-456$ Coimbra, \\ Portugal \\ ${ }^{\mathrm{d}}$ Facultad de Ciencias Químicas, INFIQC-CONICET, Universidad Nacional de Córdoba, Ciudad Universitaria, 5016 Córdoba, Argentina \\ e Department of Chemistry, University of Coimbra, 3004-535 Coimbra, Portugal
}

\section{A R T I C L E I N F O}

\section{Article history:}

Received 20 May 2015

Received in revised form 25 August 2015

Accepted 6 September 2015

Available online $\mathrm{xxx}$

\section{Keywords:}

Enemy release hypothesis

Shifting defense hypothesis

Sesquiterpene lactones

Trichomes

Lipophilicity

Novel weapons

\begin{abstract}
A B S T R A C T
Plant chemical defenses can be qualitative (toxins) to face generalist herbivores and quantitative (digestibility reducers) to specialists. Trichomes can produce chemicals, but also acts as a quantitative defense and in water loss. The shifting defense hypothesis (SDH) poses that invasive plants reduce the production of qualitative defenses against specialist herbivores because those are frequently absent in invaded regions, while increasing defenses against generalist herbivores. Chemical and physical leaf surface defensive traits could give information about direct plant-herbivore interaction in native and non-native regions. We studied leaf surface morphology and epicuticular chemistry of the invasive $C$. solstitialis in plants from native and non-native regions. Across regions, the main chemical components were sesquiterpene lactones, similar densities of sessile glandular trichomes and a variable number of large multicellular trichomes. Exotic plants face different sets of challenges in the new regions. In accordance with $\mathrm{SDH}$, plants from non-native regions presented higher total sesquiterpene lactones concentrations (qualitative defense). Trichome density was possibly associated to differences in local climatic conditions. Sesquiterpene lactones are likely to play an important role on the invasion success of Centaurea. Leaf surface components provide meaningful information that should be consider in future studies to unravel the mechanisms involved in plant invasions.
\end{abstract}

() 2015 Elsevier Ltd. All rights reserved.

* Corresponding author. Departamento de Botánica, Facultad de Ciencias Naturales y Oceanográficas, Universidad de Concepción, Víctor Lamas 1290, P.O. Box 160 C, Concepción, Chile.

E-mail addresses: gastonsotes@gmail.com (G.J. Sotes), lohencavieres@gmail.com (L.A. Cavieres), danimontesinos@gmail.com (D. Montesinos), cafe@bot. uc.pt (A.X. Pereira Coutinho), waldemar31@fcq.unc.edu.ar (W.J. Peláez), susy.lopes@live.com.pt (S.M.M. Lopes), tmelo@ci.uc.pt (T.M.V.D. Pinho e Melo). 


\section{Introduction}

Herbivory is an important selective force in plants, resulting in the development of a wide variety of chemical and physical defensive traits (Duffey and Stout, 1996; Rausher, 2001; Hanley et al., 2007). Chemically, defenses can be either qualitative or quantitative. Qualitative defenses are secondary metabolites (e.g., alkaloids) that occur at low concentrations in plant tissues and are toxic to generalist herbivores, while specialists are adapted to them. Quantitative defenses derive from the primary (e.g., cellulose) or secondary (e.g., tannins) plant metabolism and are present in high concentrations acting as digestibility reducers against specialist herbivores (Müller-Schärer et al., 2004).

The Enemy Release Hypothesis (ERH) proposed that exotic plants introduced into new regions become invasive because they "escaped" from their specialist enemies (Keane and Crawley, 2002). Under lower specialist's pressure, the Shifting Defense Hypothesis (SDH) proposes that invasive plants might reallocate resources devoted to defenses (Joshi and Vrieling, 2005). More specifically, invasive plants reduce the production of defenses against specialist (quantitative defenses) and invest more in qualitative defenses against generalist herbivores (Joshi and Vrieling, 2005), because invasive plants still suffer the attack of the local generalist herbivores (Memmott et al., 2000). Recently, a meta-analysis of SDH studies showed that qualitative compounds had a tendency to increase in the non-native regions, although that trend was not paralleled by a decrease in quantitative defenses (e.g., trichomes) (Doorduin and Vrieling, 2011). Leaf trichomes can have a dual function, both as producers of chemicals, but also as digestibility reducers, and even on control of evapotranspiration (Wagner et al., 2004). Consequently, different selective pressures act over their numbers, form, and function (Ågren and Schemske, 1994; Wagner et al., 2004; Doorduin and Vrieling, 2011).

Previous studies on SDH used entire ground leaves in chemical analysis (Doorduin and Vrieling, 2011), a method that does not discriminate between internal and leaf surface chemistry. The epicuticular chemistry is suited for the specific assessment of chemical defenses against herbivores, because most herbivores will interact first with the leaf surface and many (e.g., aphids) will only interact with it. Epicuticular chemical composition is a complex mixture of lipid components and secondary metabolites deposited over the leaf surface via diffusion and by secretory structures (Müller and Riederer, 2005). Several secondary metabolites are cues to specialist insects for oviposition and feeding, but they are deterrents and toxins against generalists (Müller and Riederer, 2005). For example, the invasive Centaurea maculosa Lam. (Asteraceae) presents sesquiterpene lactones (cnicin) located in glandular trichomes on the leaf surface (Kelsey and Locken, 1987). Larval diet tests showed that cnicin concentrations of $3 \%$ and $6 \%$ were lethal against generalist herbivores, while growth and survival of the specialist were not influenced. Also, C. maculosa specialist herbivores preferentially oviposited on cnicin-sprayed plants; where competition with other herbivores would be lower (Landau et al., 1994).

Sesquiterpene lactones have been found to be abundant for several Centaurea invasive species (Bruno et al., 2013). Among these, Centaurea solstitialis L. (yellow starthistle) is an annual herb native to the southern Europe and a noxious invasive plant in the Americas and Australia (Montesinos et al., 2012). Previous morpho-anatomical work reports the presence of glands and trichomes on leaves (Kaya et al., 2010), but there were not studies about their epicuticular chemistry.

We propose that the study of shifting defenses should be focused on the leaf surfaces, which represents the first line of plant defense that influence generalist and specialist enemies behavior (Müller and Riederer, 2005). We analyzed qualitative and quantitative defenses in $C$. solstitialis plants grown under common garden conditions originating from different native and non-native regions, with the intention to report variations in leaf surface traits as a result of different environmental pressures across large biogeographical native and non-native regions.

\section{Material and methods}

\subsection{Common garden}

Seeds of $C$. solstitialis were collected from 30 individual plants randomly chosen in four different populations in two native (Spain and Turkey) and two non-native regions (California in USA and Chile). Although the four regions have a Mediterranean-type climate, they do not share identical weather during plant growth season (spring and summer). Therefore, precipitations and temperatures of these months could be useful to assess the role of climate on trichomes density across regions. We obtained from WORLDCLIM in ESRI grids of 30 arc seconds and extracted in ArcGIS (version 10, Esri Inc., Redlands, CA, USA) (Hijmans et al., 2005) the mean precipitations and temperatures of March-July in locations of California, Spain and Turkey, and September-December for Chile (Table 1). During spring and summer of 2012 seeds were germinated in a growthchamber with a photoperiod of $12 \mathrm{~h}$ light at $20^{\circ} \mathrm{C}$ and $12 \mathrm{~h}$ darkness at $10^{\circ} \mathrm{C}$. After germination, we randomly planted 10 seedlings per region in $2 \mathrm{~L}$ pots with a $1: 2 \mathrm{v} / \mathrm{v}$ mix of sand and standard commercial soil and grew them under identical common gardening conditions, watering as necessary, in the Botanical Garden of the Coimbra University, Portugal. After three months, we harvested two leaves per plant (20 per region) for chemical analyses and two other (20 per region) for microscopy analyses (see below).

\subsection{Epicuticular chemical analyses}

One extract per region was obtained by dipping the 20 leaves of the ten different individuals from the same region in $1 \mathrm{~L}$ of $\mathrm{CH}_{2} \mathrm{Cl}_{2}$ for $30 \mathrm{~s}$. The extracts were dried and fractionated by column chromatography of silica gel using step gradients: hexane, 
Table 1

Mean precipitation and temperature during $C$. solstitialis growth season for each seed origin.

\begin{tabular}{|c|c|c|c|}
\hline Region & Location & Precipitation (mm) & Temperature $\left({ }^{\circ} \mathrm{C}\right)$ \\
\hline \multirow[t]{4}{*}{ California } & $38^{\circ} 12^{\prime} 13^{\prime \prime} \mathrm{N} 122^{\circ} 09^{\prime} 22^{\prime \prime} \mathrm{W}$ & 15 & 21.9 \\
\hline & $38^{\circ} 20^{\prime} 21^{\prime \prime} \mathrm{N} 122^{\circ} 09^{\prime} 17^{\prime \prime} \mathrm{W}$ & 15 & 21.8 \\
\hline & $38^{\circ} 24^{\prime} 38^{\prime \prime} \mathrm{N} 121^{\circ} 56^{\prime} 03^{\prime \prime} \mathrm{W}$ & 5 & 23.3 \\
\hline & $38^{\circ} 38^{\prime} 26^{\prime \prime} \mathrm{N} 121^{\circ} 09^{\prime} 23^{\prime \prime} \mathrm{W}$ & 12 & 24.1 \\
\hline \multirow[t]{4}{*}{ Chile } & $33^{\circ} 13^{\prime} 29^{\prime \prime} \mathrm{S} 70^{\circ} 30^{\prime} 45^{\prime \prime} \mathrm{W}$ & 16 & 14.2 \\
\hline & $33^{\circ} 18^{\prime} 43^{\prime \prime} \mathrm{S} 70^{\circ} 26^{\prime} 55^{\prime \prime} \mathrm{W}$ & 16 & 16.6 \\
\hline & $33^{\circ} 20^{\prime} 44^{\prime \prime} \mathrm{S} 70^{\circ} 30^{\prime} 09^{\prime \prime} \mathrm{W}$ & 6 & 19.1 \\
\hline & $33^{\circ} 25^{\prime} 10^{\prime \prime} \mathrm{S} 71^{\circ} 18^{\prime} 10^{\prime \prime} \mathrm{W}$ & 9 & 19.6 \\
\hline \multirow[t]{4}{*}{ Spain } & $36^{\circ} 50^{\prime} 24^{\prime \prime} \mathrm{N} 3^{\circ} 58^{\prime} 55^{\prime \prime} \mathrm{W}$ & 23 & 22.9 \\
\hline & $40^{\circ} 14^{\prime} 30^{\prime \prime} \mathrm{N} 2^{\circ} 41^{\prime} 15^{\prime \prime} \mathrm{W}$ & 67 & 21.5 \\
\hline & $41^{\circ} 04^{\prime} 07^{\prime \prime} \mathrm{N} 0^{\circ} 20^{\prime} 03^{\prime \prime} \mathrm{W}$ & 87 & 21.6 \\
\hline & $41^{\circ} 52^{\prime} 40^{\prime \prime} \mathrm{N}^{\circ} 46^{\prime} 42^{\prime \prime} \mathrm{W}$ & 82 & 21.7 \\
\hline \multirow[t]{4}{*}{ Turkey } & $37^{\circ} 22^{\prime} 32^{\prime \prime} \mathrm{N} 29^{\circ} 08^{\prime} 37^{\prime \prime} \mathrm{E}$ & 51 & 21.3 \\
\hline & $37^{\circ} 25^{\prime} 46^{\prime \prime} \mathrm{N} 28^{\circ} 25^{\prime} 27^{\prime \prime} \mathrm{E}$ & 42 & 23.4 \\
\hline & $37^{\circ} 33^{\prime} 50^{\prime \prime} \mathrm{N} 28^{\circ} 01^{\prime} 15^{\prime \prime} \mathrm{E}$ & 25 & 26.6 \\
\hline & $38^{\circ} 10^{\prime} 57^{\prime \prime} \mathrm{N} 28^{\circ} 02^{\prime} 03^{\prime \prime} \mathrm{E}$ & 27 & 24.8 \\
\hline
\end{tabular}

dichloromethane and ethyl acetate. Sixteen fractions were isolated per region of about $100 \mathrm{ml}$ each. All fractions were analyzed by Gas Chromatography-Mass Spectrometry (GC-MS), performed with an Agilent Tecnhologies 7820A System gas chromatograph linked to an Agilent Tecnhologies 5975 Series MSD mass spectrometric detector. The compounds separation was performed by a HP5 column ( $0.25 \mu \mathrm{m}$ film thickness, $30 \mathrm{~m} \times 0.20 \mathrm{~mm}$, Supelco Inc., Deerfield IL, USA) by using helium as eluent at a flow rate of $1 \mathrm{ml} \mathrm{min}{ }^{-1}$. The injector and ion source temperature was $250{ }^{\circ} \mathrm{C}$, the initial temperature was $40{ }^{\circ} \mathrm{C}$ (2 min) and the oven heating ramp was $8{ }^{\circ} \mathrm{C} \mathrm{min}^{-1}$ from 40 to $280^{\circ} \mathrm{C}(20 \mathrm{~min})$, and the interface temperature was $250{ }^{\circ} \mathrm{C}$. The pressure in the MS instrument was $10^{-5}$ Torr, precluding ion-molecule reactions from taking place, and MS recordings were made in the electron impact mode (EI) at ionization energy of $70 \mathrm{eV}$. The identification of the compounds was achieved by comparison of their mass spectra with a library database (NIST 2012). Spectra were considered coincident if the similarity index was higher than 95\%. Also, mass spectra of the peaks were compared with published spectrometric data. The percentage of compounds was calculated from the peak areas of the chromatograms. The fraction 13 of California's sample was re-chromatographed with a $1: 1 \mathrm{v} / \mathrm{v}$ of ethyl acetate and dichloromethane; three fractions were collected. These three new fractions as well as fraction 16 from Turkey and 11 from Spain were analyzed by nuclear magnetic resonance spectroscopy (NMR) to support the identification of sesquiterpene lactones. NMR was performed in a Bruker Avance III $400 \mathrm{MHz}$ spectrometer (BBI probe, $\mathrm{z}$ gradient) $\left({ }^{1} \mathrm{H}\right.$ at $400 \mathrm{MHz}$ and ${ }^{13} \mathrm{C}$ at $\left.100 \mathrm{MHz}\right) \cdot{ }^{1} \mathrm{H}$ and ${ }^{13} \mathrm{C}$ spectra were recorded in deuteriochloroform $\left(\mathrm{CDCl}_{3}\right)$. Chemical shifts are reported in parts per million (ppm) downfield from TMS, coupling constants $(J)$ are expressed in $\mathrm{Hz}$ and the spectra were measured at $25^{\circ} \mathrm{C}$.

\subsection{Leaf surface microscopy}

\subsubsection{Light microscopy (LM)}

After being dehydrated in a graded ethanol/xylol series, the leaf abaxial and adaxial epidermis of 10 leaves per region were mounted in DPX, photographed with a MOTIC BA 310 microscope and 15 random measures $(\times 400)$ per leaf were taken. Trichome density was estimated by counting the number of trichomes that intersected to a diagonal line from the top left corner to the bottom right corner of the field.

\subsubsection{Scanning electron microscopy (SEM)}

After being air dried, fragments of 10 leaves per region was mounted on aluminum stubs, coated with gold-palladium with an ion-sputter and observed with a Hitachi SU-70 (5 kV) SEM microscope and 9 random measures per leaf were taken. Gland and trichome density were estimated by counting directly on the SEM image $(\times 200)$ the number of trichomes intersecting a diagonal line between the top left corner and the bottom right corner of the image.

\subsection{Statistical analyses}

Leaf surface data were analyzed with R 2.13 .0 software with a significance threshold of $P=0.05$. Chemical data were analyzed by using proportion tests with the package ctest, and morphological data with linear mixed-effects models with the package nlme. Trichomes densities from LM and SEM were tested and found to be similar within region and were thus pooled together for subsequent analyses. The number of trichomes or glands were used as variables, and individuals were treated as random effects nested within the fixed factor, region. The within-group errors were allowed to be correlated and/or have unequal variances. Tukey post-hoc multiple comparisons were run to discriminate for differences among regions with the procedure glht from the R package multcomp. 


\section{Results}

\subsection{Epicuticular chemical analyses}

According to the results obtained by GC-MS and NMR, we have been able to identify the $91.26 \%$ of total chromatogram peak of Californian extract, $87.91 \%$ of Chilean, $91.17 \%$ of Spanish and 85.84\% of Turkish (Table 2). Epicuticular extracts of $C$. solstitialis contain long chain alkanes $\left(\mathrm{C}_{21}-\mathrm{C}_{31}\right)$ and waxes (alcohols, aldehydes, esters) (fractions 1-4), pentacyclic triterpenes (fractions 5-11), and a great abundance of sesquiterpene lactones (fractions 12-16) (Fig. 1, Table 2). The proportion of long chain alkanes, waxes and pentacyclic triterpenes varied among regions (Fig. 2). However, in all regions the main chain alkanes were $C_{27}$ and $C_{29}$, and the pentacyclic triperpenes were $\alpha$-amirym, $\beta$-amirym, taraxasterol (Table 2 ).

Regarding the more polar fractions, twelve sesquiterpene lactones were identified based upon on their mass and NMR spectra: desacylcynaropicrin (1), solstitialin (2), solstitialin A-13 acetate (3), solstitialina A-3 acetate (4), aguerin B (5), epoxyrepdiolide derivative (6), repin (7), subluteolide (8), janerin (9), solstitialin A-3, 13 diacetate (10), linichlorin A (11) and acroptilin (12) (Fig. 3). Most of them have been found in C. solstitialis (Bruno et al., 2013); however, compounds 6, 10 and 11 are reported for first time in the present study. Therefore, we report the ${ }^{1} \mathrm{H}$ and ${ }^{13} \mathrm{C}$ NMR spectral assignments of these compounds (Tables 3 and 4). Sesquiterpene lactones structures and their presumed abbreviated biosynthetic pathway are show in Fig. 3 (Corbella et al., 1972; Seaman, 1982; Majdi et al., 2011; Lange and Turner, 2012). Previous work with dried and ground plant material found solstitialin A as the major sesquiterpene lactone of C. solstitialis (Merrill and Stevens, 1985). However, in our work the main compound on the surface of fresh leaves was repin (7) in plants from California, Chile and Spain; and in Turkey was the repin's isomer subluteolide (8). Solstitialin A-13 acetate (3), epoxyrepdiolide derivative (6) and janerin (9)

Table 2

Composition and percentage of epicuticular chemical components found in leaves of $C$. sosltitialis from native and non-native regions identified by GC-MS.

\begin{tabular}{|c|c|c|c|c|c|}
\hline Compounds & & California & Chile & Spain & Turkey \\
\hline \multicolumn{6}{|l|}{ Alkanes } \\
\hline $\mathrm{C}_{21} \mathrm{H}_{44}$ & & $\operatorname{tr}$ & $\operatorname{tr}$ & $\operatorname{tr}$ & $\operatorname{tr}$ \\
\hline $\mathrm{C}_{22} \mathrm{H}_{46}$ & & $\operatorname{tr}$ & 0.08 & $\operatorname{tr}$ & 0.08 \\
\hline $\mathrm{C}_{23} \mathrm{H}_{48}$ & & $\operatorname{tr}$ & 0.09 & 0.05 & 0.07 \\
\hline $\mathrm{C}_{24} \mathrm{H}_{50}$ & & $\operatorname{tr}$ & 0.07 & $\operatorname{tr}$ & 0.1 \\
\hline $\mathrm{C}_{25} \mathrm{H}_{52}$ & & 0.11 & 0.17 & 0.11 & 0.26 \\
\hline $\mathrm{C}_{26} \mathrm{H}_{54}$ & & 0.05 & $\mathrm{tr}$ & 0.04 & 0.21 \\
\hline $\mathrm{C}_{27} \mathrm{H}_{56}$ & & 2.16 & 2.97 & 1.68 & 2.81 \\
\hline $\mathrm{C}_{28} \mathrm{H}_{58}$ & & 0.15 & 0.06 & 0.1 & 0.36 \\
\hline $\mathrm{C}_{29} \mathrm{H}_{60}$ (linear) & & 2.25 & 3.37 & 1.69 & 3 \\
\hline $\mathrm{C}_{29} \mathrm{H}_{60}$ (branched) & & 0.28 & $\operatorname{tr}$ & 0.3 & 0.92 \\
\hline $\mathrm{C}_{30} \mathrm{H}_{62}$ & & 0.05 & $\operatorname{tr}$ & $\operatorname{tr}$ & 0.18 \\
\hline $\mathrm{C}_{31} \mathrm{H}_{64}$ (linear) & & 0.54 & 1.06 & 0.43 & 0.85 \\
\hline $\mathrm{C}_{31} \mathrm{H}_{64}$ (branched) & & 0.7 & $\mathrm{tr}$ & 0.27 & 1.36 \\
\hline \multicolumn{6}{|l|}{ Waxes } \\
\hline Alcohols, aldehydes and esters & & 7.67 & 4.49 & 14.3 & 6.4 \\
\hline \multicolumn{6}{|l|}{ Pentacyclic triterpenes } \\
\hline $\mathrm{C}_{30} \mathrm{H}_{50} \mathrm{O}$, lupeol & & 0.22 & $\operatorname{tr}$ & $\operatorname{tr}$ & $\operatorname{tr}$ \\
\hline $\mathrm{C}_{30} \mathrm{H}_{50} \mathrm{O}, \alpha$-amyrin & & 0.48 & 0.74 & 0.84 & 2 \\
\hline $\mathrm{C}_{30} \mathrm{H}_{50} \mathrm{O}, \beta$-amyrin & & 0.6 & 1.57 & 0.45 & 2.4 \\
\hline $\mathrm{C}_{30} \mathrm{H}_{50} \mathrm{O}$, taraxasterol & & 0.42 & 0.88 & 0.34 & 1.07 \\
\hline $\mathrm{C}_{32} \mathrm{H}_{52} \mathrm{O}_{2}$, lupeol acetate & & 0.15 & 0.1 & $\operatorname{tr}$ & $\operatorname{tr}$ \\
\hline $\mathrm{C}_{32} \mathrm{H}_{52} \mathrm{O}_{2}, \alpha$-amyrin acetate & & $\operatorname{tr}$ & $\operatorname{tr}$ & $\operatorname{tr}$ & $\operatorname{tr}$ \\
\hline $\mathrm{C}_{32} \mathrm{H}_{52} \mathrm{O}_{2}, \beta$-amyrin acetate & & 0.25 & $\operatorname{tr}$ & 1.44 & $\operatorname{tr}$ \\
\hline $\mathrm{C}_{32} \mathrm{H}_{52} \mathrm{O}_{2}$, taraxasterol acetate & & 0.12 & 0.05 & $\operatorname{tr}$ & $\operatorname{tr}$ \\
\hline \multicolumn{6}{|l|}{ Sesquiterpene lactones } \\
\hline $\mathrm{C}_{15} \mathrm{H}_{18} \mathrm{O}_{4}$, desacylcynaropicrin & 1.92 & & 0.5 & 1.09 & 0.32 \\
\hline $\mathrm{C}_{15} \mathrm{H}_{20} \mathrm{O}_{5}$, solstitialin & 0.3 & & 0.08 & 1.44 & 0.63 \\
\hline $\mathrm{C}_{17} \mathrm{H}_{22} \mathrm{O}_{6}$, solstitialin A-13 acetate & 10.2 & & 1.22 & 9.42 & 7.5 \\
\hline $\mathrm{C}_{17} \mathrm{H}_{22} \mathrm{O}_{6}$, solstitialin $\mathrm{A}-3$ acetate & $\operatorname{tr}$ & & $\operatorname{tr}$ & 0.7 & $\operatorname{tr}$ \\
\hline $\mathrm{C}_{19} \mathrm{H}_{22} \mathrm{O}_{5}$, aguerin $\mathrm{B}$ & $\operatorname{tr}$ & & $\operatorname{tr}$ & 0.06 & 0.54 \\
\hline $\mathrm{C}_{19} \mathrm{H}_{22} \mathrm{O}_{6}$, epoxyrepdiolide & 1.59 & & 1.39 & 0.77 & 2.3 \\
\hline $\mathrm{C}_{19} \mathrm{H}_{22} \mathrm{O}_{7}$, repin & 40.2 & & 42.4 & 33.9 & 13 \\
\hline $\mathrm{C}_{19} \mathrm{H}_{22} \mathrm{O}_{7}$, subluteolide & 15.8 & & 19.5 & 12.4 & 25.85 \\
\hline $\mathrm{C}_{19} \mathrm{H}_{22} \mathrm{O}_{7}$, janerin & 3.12 & & 4.66 & 0.77 & 4 \\
\hline $\mathrm{C}_{19} \mathrm{H}_{24} \mathrm{O}_{7}$, solstitialin $\mathrm{A}-3,13$ diacetate & $\operatorname{tr}$ & & $\operatorname{tr}$ & 8.1 & $\operatorname{tr}$ \\
\hline $\mathrm{C}_{19} \mathrm{H}_{23} \mathrm{ClO}_{6}$, linichlorin $\mathrm{A}$ & $\operatorname{tr}$ & & $\operatorname{tr}$ & $\operatorname{tr}$ & 9.62 \\
\hline $\mathrm{C}_{19} \mathrm{H}_{23} \mathrm{ClO}_{7}$, acroptilin & 1.93 & & 2.46 & 0.48 & 0.01 \\
\hline \multicolumn{6}{|l|}{ Total } \\
\hline Lipid components & 16.2 & & 15.7 & 22.04 & 22.07 \\
\hline Sesquiterpene lactones & 75.06 & & 72.21 & 69.13 & 63.77 \\
\hline Components identified & 91.26 & & 87.91 & 91.17 & 85.84 \\
\hline
\end{tabular}

tr: trace amounts $<0.05 \%$. 


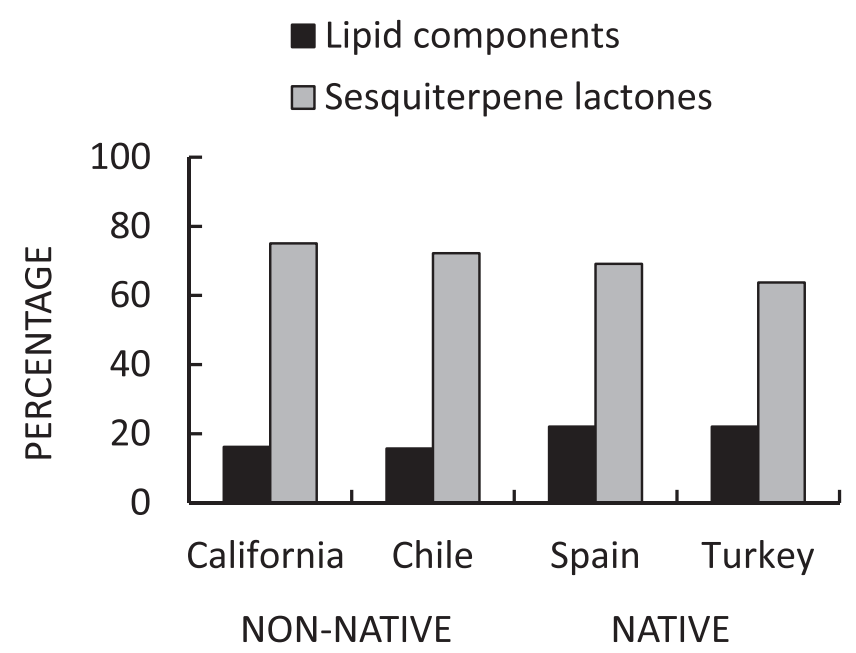

Fig. 1. Percentages of total lipid components and sesquiterpene lactones present in epicuticular extracts of $C$. solstitialis from each native and non-native regions.

(other isomer of repin) were found in small proportions (Fig. 4). Solstitialin A-3 acetate (4) and solstitialin A-3, 13 diacetate (10) were only identified in extracts from Spain. On the other hand, linichlorin A (11) was identified solely in extracts from Turkey (Table 1). In accordance with SDH the total sesquiterpene lactones present a slight increase in plants from non-native regions (Fig. 1), but statistical differences were non-significant. However, the main compound repin, showed significant higher concentration in California, Chile and Spain with regard to Turkey (Table 5).

\title{
3.2. Leaf surface microscopy
}

The SEM showed the same type of glands and multicellular trichomes with long whip-like terminal cell on leaves surface in regions, native and non-native (Fig. 5). In all regions, there was a significantly lower trichomes density on the upper leaf side (adaxial) than the lower leaf side (abaxial) $\left(F_{1,1}=36.187 ; P<0.001\right)$. Adaxial trichomes density did not differ among regions (mean $\pm \mathrm{SE} ; 10.46 \pm 2.23$ hairs $\mathrm{mm}^{-2} ; F_{1,3}=0.056 ; P=0.982$ ). However, abaxial trichomes density differed significantly among regions, with higher densities in Turkish plants, intermediate in California, and lower densities in Chilean and Spanish plants $\left(F_{1,3}=4.689 ; P=0.005\right)$. We estimated glands density on the abaxial side to analyze their contribution on the amount of sesquiterpene lactones found in every region. Leaves from Chile presented significantly lower densities of glands than Californian and Spanish leaves, whereas Turkey presented intermediate values $\left(F_{1,2}=3.231 ; P=0.082\right)$ (Fig. 6).

\section{Discussion}

Across regions, C. solstitialis leaf surfaces presented high amounts of qualitative defense (sesquiterpene lactones) against generalist herbivores and a variable number of trichomes (quantitative defense) against specialist herbivores. The results

\author{
- Alkanes \\ $\square$ Waxes \\ $\square$ Pentacyclic triterpenes
}

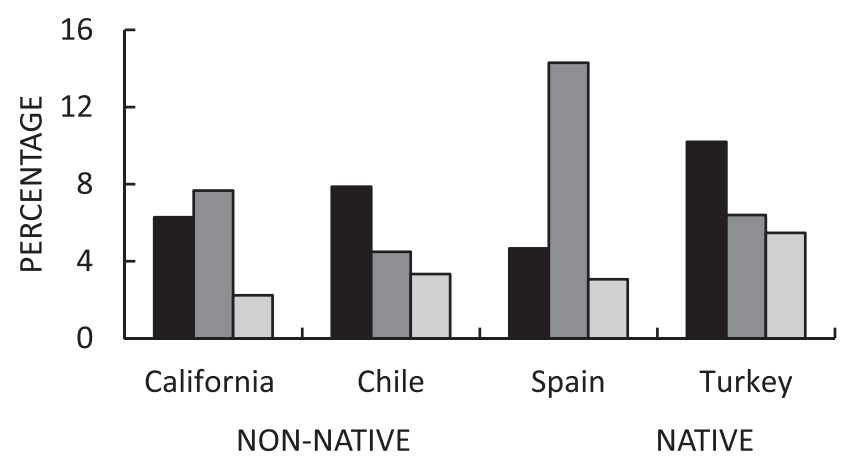

Fig. 2. Percentages of lipid components present in epicuticular extracts of $C$. solstitialis from each native and non-native regions. 


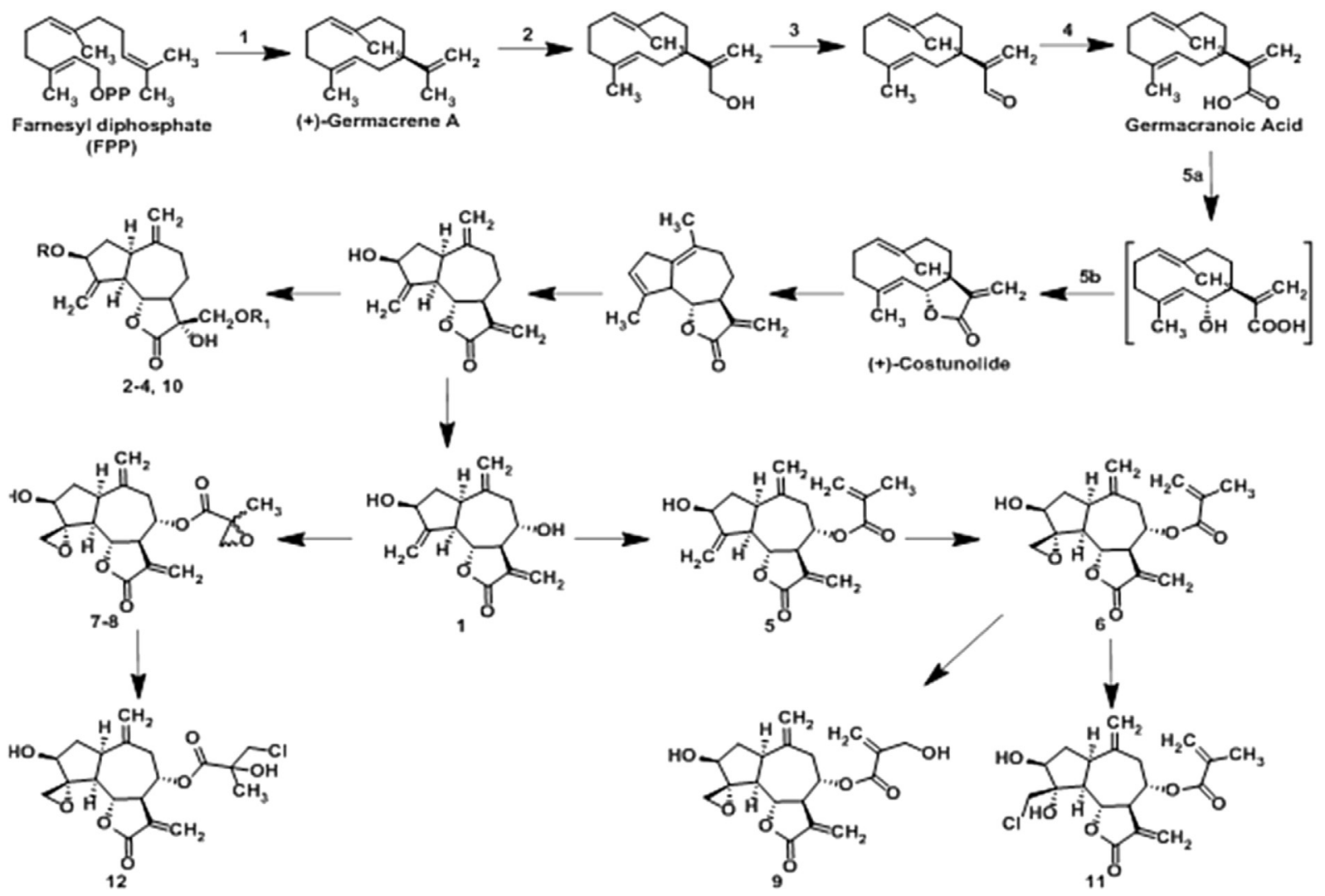

Fig. 3. Structure and presumed abbreviated biosynthetic pathway of the sesquiterpene lactones found in extracts of $C$. solstitialis; step1 is catalyzed by germacrene A synthase; steps 2, 3 and 4 are catalyzed by germacrene A oxidase; step 5a, 5b: costunolide synthase.

showed variation among regions in the amounts of every sesquiterpene lactone. Their uses as taxonomic markers often show intraspecific variation, or chemotypes, for many Asteraceae species (Seaman, 1982). Several studies have reported the high toxicity of sesquiterpene lactones against bacteria, fungi, herbivores, and plants (allelopathy) (Seaman, 1982; Picman, 1986; Bruno et al., 2013). Previous works with Centaurea invasive species suggest that sesquiterpene lactones may play an important role in their success in non-native regions (Muir and Majak, 1983; Locken and Kelsey, 1987; Kelsey and Locken,

Table 3

${ }^{1} \mathrm{H}$ NMR data of compounds 6,10 and 11 in $\mathrm{CDCl}_{3}$.

\begin{tabular}{llll}
\hline & Compound & & \\
\cline { 2 - 4 } & 6 & 10 & 11 \\
\hline $\mathrm{H}-1$ & $3.35-3.38(\mathrm{~m})$ & $2.89-2.93(\mathrm{~m})$ & $3.33(\mathrm{q}, J=9.5 \mathrm{~Hz})$ \\
$\mathrm{H}-2 \mathrm{a}$ & $2.46-2.52(\mathrm{~m})$ & $2.45-2.49(\mathrm{~m})$ & $2.35-2.44(\mathrm{~m})$ \\
$\mathrm{H}-2 \mathrm{~b}$ & $1.81-1.88(\mathrm{~m})$ & $1.96-2.03(\mathrm{~m})$ & $172-1.76(\mathrm{~m})$ \\
$\mathrm{H}-3$ & $3.99-4.01(\mathrm{~m})$ & $5.54(\mathrm{t}, J=7.1 \mathrm{~Hz})$ & $4.19(\mathrm{t}, J=5.7 \mathrm{~Hz})$ \\
$\mathrm{H}-5$ & $2.04-2.11(\mathrm{~m})$ & $2.85-2.89(\mathrm{~m})$ & \\
$\mathrm{H}-6$ & $4.60-4.65(\mathrm{~m})$ & $4.07-4.09(\mathrm{~m})$ & $4.56(\mathrm{t}, J=10.1 \mathrm{~Hz})$ \\
$\mathrm{H}-7$ & $3.09-3.12(\mathrm{~m})$ & $2.49 .2 .53(\mathrm{~m})$ & $3.13-3.18(\mathrm{~m})$ \\
$\mathrm{H}-8$ & $5.12\left(\mathrm{ddd}, J_{1}=9.0 \mathrm{~Hz}, J_{2}=6.6 \mathrm{~Hz}, J_{3}=4.5 \mathrm{~Hz}\right)$ & $1.77-1.85(\mathrm{~m}) \mathrm{and} 1.34-1.44(\mathrm{~m})$ & $5.05\left(\mathrm{ddd}, J_{1}=9.8 \mathrm{~Hz}, J_{2}=7.2 \mathrm{~Hz}, J_{3}=4.7 \mathrm{~Hz}\right)$ \\
$\mathrm{H}-9 \mathrm{a}$ & $2.76\left(\mathrm{dd}, J_{1}=14.6 \mathrm{~Hz}, J_{2}=3.5 \mathrm{~Hz}\right)$ & $2.56-2.61(\mathrm{~m})$ & $2.80\left(\mathrm{dd}, J_{1}=14.2 \mathrm{~Hz}, J_{2}=4.9 \mathrm{~Hz}\right)$ \\
$\mathrm{H}-9 \mathrm{~b}$ & $2.42\left(\mathrm{dd}, J_{1}=14.6 \mathrm{~Hz}, J_{2}=5.0 \mathrm{~Hz}\right)$ & $2.14-2.18(\mathrm{~m})$ & $2.28\left(\mathrm{dd}, J_{1}=14.2 \mathrm{~Hz}, J_{2}=4.7 \mathrm{~Hz}\right)$ \\
$\mathrm{H}-13 \mathrm{a}$ & $6.21(\mathrm{~d}, J=3.3 \mathrm{~Hz})$ & $4.33(\mathrm{~d}, J=11.8 \mathrm{~Hz})$ & $6.22(\mathrm{~d} J=3.1 \mathrm{~Hz})$ \\
$\mathrm{H}-13 \mathrm{~b}$ & $5.60(\mathrm{~d}, J=3.3 \mathrm{~Hz})$ & $4.08(\mathrm{~d}, J=11.8 \mathrm{~Hz})$ & $5.16(\mathrm{~d})$ \\
$\mathrm{H}-14 \mathrm{a}$ & $5.18(\mathrm{~s})$ & $4.95(\mathrm{~s})$ & $4.1 \mathrm{~Hz})$ \\
$\mathrm{H}-14 \mathrm{~b}$ & $4.96(\mathrm{~s})$ & $4.92(\mathrm{~s})$ & $4.97(\mathrm{~s})$ \\
$\mathrm{H}-15 \mathrm{a}$ & $5.35(\mathrm{~d}, J=4.1 \mathrm{~Hz})$ & $5.41(\mathrm{~s})$ & $4.96(\mathrm{~d}, J=12.0 \mathrm{~Hz})$ \\
$\mathrm{H}-15 \mathrm{~b}$ & $3.07(\mathrm{~d}, J=4.1 \mathrm{~Hz})$ & $5.31(\mathrm{~s})$ & \\
$\mathrm{H}-17$ & & $2.10(\mathrm{~s})$ & $6.18(\mathrm{~s})$ \\
$\mathrm{H}-18 \mathrm{~Hz}$ & $6.18(\mathrm{~s})$ & & $5.68(\mathrm{~s})$ \\
$\mathrm{H}-18 \mathrm{~b}$ & $5.68(\mathrm{~s})$ & $2.08(\mathrm{~s})$ & $1.99(\mathrm{~s})$ \\
H-19 & $1.99(\mathrm{~s})$ & & \\
\hline
\end{tabular}


Table 4

${ }^{13} \mathrm{C}$ NMR data of compounds 6,10 and 11 in $\mathrm{CDCl}_{3}$.

\begin{tabular}{lrrr}
\hline & Compound & & \\
\cline { 2 - 4 } & \multicolumn{1}{c}{6} & 10 & 11 \\
\hline C-1 & 45.9 & 44.4 & 43.7 \\
C-2 & 36.7 & 36.8 & 36.7 \\
C-3 & 76.5 & 75.5 & 78.2 \\
C-4 & 68.4 & 149.3 & 83.4 \\
C-5 & 53.2 & 53.0 & 55.2 \\
C-6 & 77.5 & 82.5 & 77.4 \\
C-7 & 48.2 & 51.0 & 47.9 \\
C-8 & 74.1 & 27.7 & 74.2 \\
C-9 & 37.8 & 36.7 & 38.9 \\
C-10 & 141.6 & 148.5 & 141.8 \\
C-11 & 76.3 & 136.6 \\
C-12 & 137.3 & 176.7 & 169.4 \\
C-13 & 64.9 & 123.7 \\
C-14 & 169.1 & 115.0 & 117.5 \\
C-15 & 122.8 & 114.0 & 63.9 \\
C-16 & 118.7 & 171.2 & 166.4 \\
C-17 & 48.6 & 22.0 & 136.1 \\
C-18 & 166.5 & 171.5 & 126.8 \\
C-19 & 136.1 & 21.4 & 18.2 \\
\hline
\end{tabular}

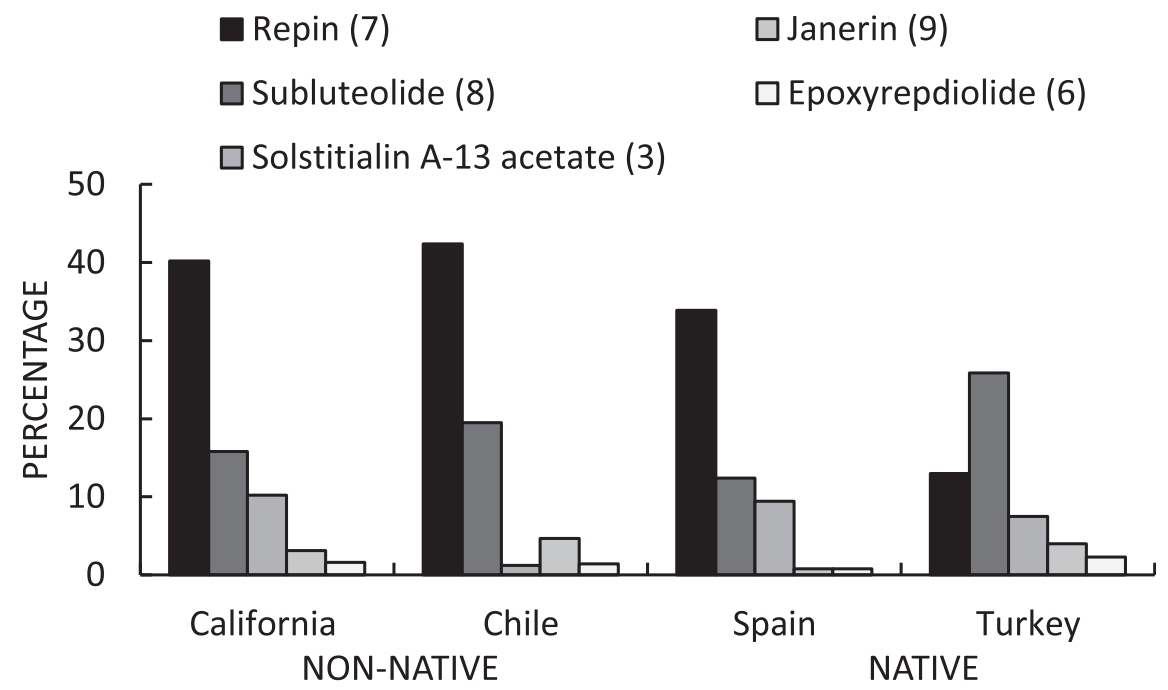

Fig. 4. Percentages of the main sesquiterpene lactones present in the epicuticular extracts of $C$. solstitialis from each native and non-native regions.

1987; Stevens et al., 1990; Landau et al., 1994). The novel weapons hypothesis (NWH) proposes that invasive plants introduce chemicals which are new to the non-native areas that they invade, and for which native organisms are not adapted (Callaway and Ridenour, 2004), resulting in competitive advantages to invasive plants (Agrawal et al., 2005). For example, root exudates of Centaurea diffusa are known to present such allelopathic effects over native grass species (Callaway and Aschehoug, 2000).

Table 5

Proportion test between regions of the total sesquiterpene lactones and the main compound repin.

\begin{tabular}{|c|c|c|c|c|}
\hline & \multicolumn{2}{|c|}{ Total sesquiterpene lactones } & \multicolumn{2}{|l|}{ Repin } \\
\hline & $Z$ & $P$ & $Z$ & $P$ \\
\hline California vs. Chile & 0.105 & 0.920 & 0.506 & 0.61 \\
\hline California vs. Spain & 1.094 & 0.276 & 0.905 & 0.363 \\
\hline California vs. Turkey & 1.295 & 0.194 & 4.187 & $<0.001$ \\
\hline Chile vs. Spain & 0.98 & 0.327 & 1.402 & 0.162 \\
\hline Chile vs. Turkey & 1.181 & 0.238 & 4.626 & $<0.001$ \\
\hline Spain vs. Turkey & 0.216 & 0.826 & 3.35 & $<0.001$ \\
\hline
\end{tabular}

Significant values are highlighted in bold. 


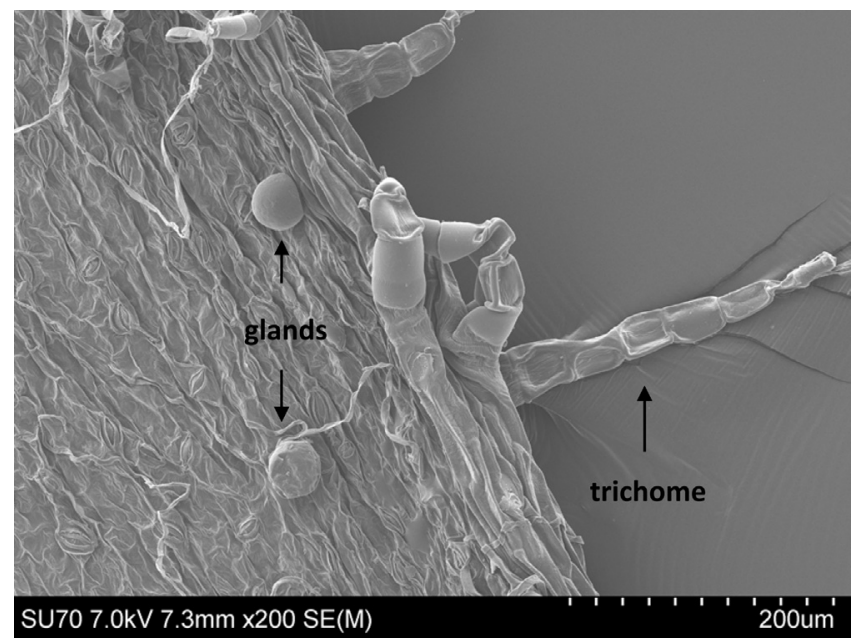

Fig. 5. SEM image of a typical C. solstitialis leaf with glands and trichomes.

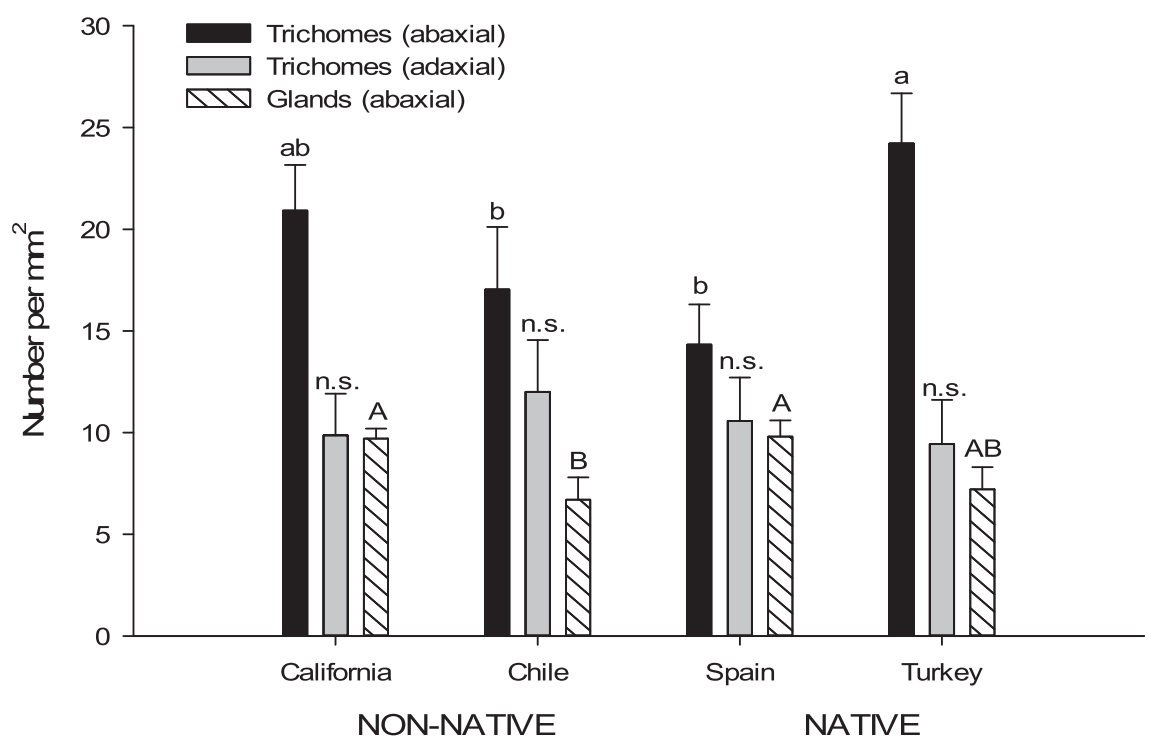

Fig. 6. Trichomes density (mean $\pm \mathrm{SE}$ ) for abaxial and adaxial sides, and glandular density for abaxial side, for each region. Different uppercase or lowercase letters independently indicate statistically significant differences.

In our study, plants from non-native regions showed an increase in total sesquiterpene lactone concentration, particularly for the main compound repin (7), which could be selected for if it confers a competitive advantage in non-native regions (Callaway and Ridenour, 2004). This compound exhibits toxic effects on animals and plants, including fatal neurological disorders like the equine nigropallidal encephalomalacia (ENE) (Stevens et al., 1990; Bruno et al., 2013). The less abundant sesquiterpene lactones are also known by their biological activity, for example, solstitialin A-13 acetate (3) and subluteolide (8) may contribute to ENE in horses too, janerin (9) showed antifeedant properties against insects and acroptilin (12) inhibited lettuce root elongation (Bruno et al., 2013).

Sesquiterpene lactones are normally associated with secreted trichomes and specialized gland cells distributed over plant surfaces (Lange and Turner, 2012). In accordance with Kaya et al. (2010), we found glands or sessile glandular trichomes and large multicellular trichomes with terminal long whip. Gland abundance was very similar among regions whereas sesquiterpene lactones concentrations were variable, resulting in no direct correlation between gland density and chemical concentration on the leaf surface. Epidermis folds or cavities and schizogen secretory canals were reported (Kaya et al., 2010) and the sesquiterpene lactones exudates can accumulate over time covering the leaf surface (Seaman, 1982). Since the chemical technique extraction "cleans" the leaf surface, our results suggest that actual chemical concentration could be more influenced by the productivity of secretory structures than by their abundance. 
Sesquiterpene lactonesover the leaf surface could act either as a cue in the host recognition by specialist herbivores, as adefensive barrier against many organisms and as an allelopathic agent leached to the soil, since Centaurea soslstitialis presents a prostrate rosette with leaves in direct contact with the soil. Our estimation of the theoretical lipophilicity of the sesquiterpene lactones with the program ACD/Lab Chemsketch V.6.0 (Table 6) showed that compounds 5, 6, 10 and 11 are hydrophobic. This affinity for lipid components allows permeability in biological membranes facilitating the toxic action of sesquiterpenes lactones (Beekman et al., 1997; Kasim et al., 2003). On the contrary, the compounds 1, 2, 3, 4, 7, 8, 9 and 12 present hydrophilic properties; theoretically, may allow them to be leached to the environment with potential allelopathic activity. Previous work found no evidence for root-mediated allelopathy of $C$. solstitialis, however, such studies focused on root exudates and do not preclude the potential allelopathic activity of foliage leachates (Qin et al., 2007). Even though we haven't tested the allelopathic effects of $C$. solstitialis leaf leachates, sesquiterpenes lactones and leaf extracts of closely related species have been reported to inhibit the germination and seedling growth of several species tested (Muir and Majak, 1983; Kelsey and Locken, 1987).

Lipid components can be versatile in their functions (Müller and Riederer, 2005). Our results show a trend toward reduced lipid components in non-native regions (Fig. 1). This could be related to both a reallocation of resources due to enemy release and an adaptive response to local climatic conditions. Several Chrysomelid leaf beetle species are stimulated to get feed by the presence of epicuticular lipids isolated from the leaf surface of their host plants (Adati and Matsuda, 1993; Lin et al., 1998). Also a waxy epicuticle can protect against photoinhibition and water lost in warm environments (Robinson et al., 1993), although excessive lipid components can occlude the stomata reducing gas-exchange and photosynthesis rates (Mohammadian et al., 2007).

Variations on leaf surface structures could be adaptive responses to different environments across region. Previous works have found inter-regional variation on leaf macro-morphological traits in C. solstitialis (Eriksen et al., 2012), and studies did find regional variation in trichome density for some regions but not for others (Blair and Wolfe, 2004; Ridenour et al., 2008). From a biophysical point of view, trichome density is functionally associated to temperature and water availability. Low trichome densities are beneficial at high temperature when soil moisture is high, because transpiration helps to reduce leaf temperature; however, under dry conditions high trichome density helps to decrease transpiration rates and to maintain the plant's water balance (Ehleringer, 1982). In our study, Turkish sites experienced higher temperature and lower precipitation (median $24{ }^{\circ} \mathrm{C} ; 36.2 \mathrm{~mm}$ ) than Spanish sites (median $21.9^{\circ} \mathrm{C} ; 64.8 \mathrm{~mm}$ ). Coherently, we found that leaves from Turkish plants presented higher abaxial trichome density than the ones from Spain. In the non-native regions, leaves from California and Chile did not differ in abaxial trichome densities, even though sites in California were warmer than in Chile (median $22.8^{\circ} \mathrm{C}$ and $17.4{ }^{\circ} \mathrm{C}$, respectively), and although both sites presented similarly low precipitation (median $11.8 \mathrm{~mm}$ ) (Table 1 ). In this context, our data is in agreement with those of Doorduin and Vrieling (2011) which suggested that different selective forces could be acting simultaneously on trichome densities.

In conclusion, $C$. solstitialis leaf surfaces showed significant chemical and morphological variations across regions. In general, studies that evaluated post-establishment traits expressions did not consider other selective pressures, different genetic origins and the trait's evolvability, which could also be responsible for the changes observed in chemical production and trichome density (Atwood and Meyerson, 2011; Dlugosch et al., 2013; Eriksen et al., 2014). Although our work was merely descriptive, such differences have the potential to defend the plants against the particular set of selective pressures found at each region, and thus to contribute to both its survival and invasiveness in the native and non-native regions. Remarkably, the trait-shifts detected in our study, as well as other previously reported macro-morphological trait-shifts must have occurred in less than 200 years since the introduction of C. solstitialis in America (Hierro et al., 2006; Graebner et al., 2012; Montesinos et al., 2012; García et al., 2013; Eriksen et al., 2014). Novel chemicals seem to play a particularly important role on invasion success, and almost half (42.8\%) of invasive plants in North America possess secondary compounds with multiple toxic effects which were previously unknown by native communities (Cappuccino and Arnason, 2006). We suggest that future studies of above-ground chemistry of invasive plants should consider leaf surface components, in order to more accurately assess the chemical mechanisms involved in biological invasions.

Table 6

Theoretical lipophilicity of the sesquiterpene lactones found on leaves surface of $C$. sosltitialis from native and non-native regions.

\begin{tabular}{|c|c|c|}
\hline Compound & & $\log (P)$ \\
\hline 1 & Desacylcynaropicrin & 0.42 \\
\hline 2 & Solstitialin & -0.24 \\
\hline 3 & Solstitialin A-13 acetate & 0.61 \\
\hline 4 & Solstitialina A-3 acetate & 0.63 \\
\hline 5 & Aguerin & 2.16 \\
\hline 6 & Epoxyrepdiolide derivative & 1 \\
\hline 7 & Repin & -0.34 \\
\hline 8 & Subluteolide & -0.34 \\
\hline 9 & Janerin & 0.18 \\
\hline 10 & Solstitialin A-3, 13 acetate & 1.48 \\
\hline 11 & Linichlorin A & 1.61 \\
\hline 12 & Acroptilin & 0.05 \\
\hline
\end{tabular}




\section{Acknowledgments}

GJS and LAC thank MECESUP UCO-0708, CONICYT (21100246/2010), PFB-023 and FICM P05-002 supporting the Institute of Ecology and Biodiversity (IEB). DM was funded by FCT (PCT/BIA-PLA/3389/2012; and IF-00066-2013) and EC (FP7-PEOPLEMC-CIG-321909).SMML thanks to FCT (Grant SFRH/BD/45128/2008; Project PEst-C/QUI/UI0313/2011), FEDER, COMPETE and QREN for financial support. The authors acknowledge the Nuclear Magnetic Resonance Laboratory of the Coimbra Chemical Centre (www.nmrccc.uc.pt), University of Coimbra for obtaining the NMR data. WJP acknowledge the National Scientific and Technical Research Council (CONICET).

\section{References}

Adati, T., Matsuda, K., 1993. Feeding stimulants for various leaf beetles (Coleoptera: Chrysomelidae) in the leaf surface wax of their host plants. Appl. Entomol. Zool. 28, 319-324.

Agrawal, A.A., Kotanen, P.M., Mitchell, C.E., Power, A.G., Godsoe, W., Klironomos, J., 2005. Enemy release? an experiment with congeneric plant pairs and diverse above- and belowground enemies. Ecology 86, 2979-2989.

Ågren, J., Schemske, D.W., 1994. Evolution of trichome number in a naturalized population of Brassica rapa. Am. Nat. 143, 1-13.

Atwood, J.P., Meyerson, L.A., 2011. Beyond EICA: understanding post-establishment evolution requires a broader evaluation of potential selection pressures. NeoBiota 10, 7-25.

Beekman, A.C., Woerdenbag, H.J., van Uden, W., Pras, N., Konings, A.W.T., Wikström, H.V., Schmidt, T.J., 1997. Structure-cytotoxicity relationships of some helenanolide-type sesquiterpene lactones. J. Nat. Prod. 60, 252-257.

Blair, A.C., Wolfe, L.M., 2004. The evolution of an invasive plant: an experimental study with Silene latifolia. Ecology 85, 3035-3042.

Bruno, M., Bancheva, S., Rosselli, S., Maggio, A., 2013. Sesquiterpenoids in subtribe Centaureinae (Cass.) Dumort (tribe Cardueae, Asteraceae): distribution, ${ }^{13} \mathrm{C}$ NMR spectral data and biological properties. Phytochemistry 95, 19-93.

Callaway, R.M., Aschehoug, E.T., 2000. Invasive plants versus their new and old neighbors: a mechanism for exotic invasion. Science 290, $521-523$.

Callaway, R.M., Ridenour, W.M., 2004. Novel weapons: invasive success and the evolution of increased competitive ability. Front. Ecol. Environ. 2, $436-443$.

Cappuccino, N., Arnason, J.T., 2006. Novel chemistry of invasive exotic plants. Biol. Lett. 2, 189-193.

Corbella, A., Gariboldi, P., Jommi, G., Samek, Z., Holub, M., Drożdż, B., Błoszyk, E., 1972. Absolute stereochemistry of cynaropicrin and relates guaianolides. J. Chem. Soc. Chem. Comm. 7, 386-387.

Dlugosch, K.M., Lai, Z., Bonin, A., Hierro, J., Rieseberg, L.H., 2013. Allele identification for transcriptome-based population genomics in the invasive plant centaurea solstitialis. G3 Genes|Genomes|Genet. 3, 359-367.

Doorduin, L.J., Vrieling, K., 2011. A review of the phytochemical support for the shifting defence hypothesis. Phytochem. Rev. 10 , 99-106.

Duffey, S.S., Stout, M.J., 1996. Antinutritive and toxic components of plant defense against insects. Arch. Insect Biochem. $32,3-37$.

Ehleringer, J., 1982. The influence of water stress and temperature on leaf pubescence development in Encelia farinose. Am. J. Bot. 69, 670-675.

Eriksen, R.L., Desronvil, T., Hierro, J.L., Kesseli, R., 2012. Morphological differentiation in a common garden experiment among native and non-native specimens of the invasive weed yellow starthistle (Centaurea solstitialis). Biol. Invasions 14, 1459-1467.

Eriksen, R.L., Hierro, J.L., Eren, Ö., Andonian, K., Török, K., Becerra, P.I., Montesinos, D., Khetsuriani, L., Diaconu, A., Kesseli, R., 2014. Dispersal pathways and genetic differentiation among worldwide populations of the invasive weed Centaurea solstitialis L. (Asteraceae). Plos One 9, e114786.

García, Y., Callaway, R.M., Diaconu, A., Montesinos, D., 2013. Invasive and non-invasive congeners show similar trait shifts between their same native and non-native ranges. Plos One 8, e82281.

Graebner, R.C., Callaway, R.M., Montesinos, D., 2012. Invasive species grows faster, competes better, and shows greater evolution toward increased seed size and growth than exotic non-invasive congeners. Plant Ecol. 213, 545-553.

Hanley, M.E., Lamont, B.B., Fairbanks, M.M., Rafferty, C.M., 2007. Plant structural traits and their role in anti-herbivore defence. Perspect. Plant Ecol. 8, $157-178$.

Hierro, J.L., Villarreal, D., Eren, Ö., Graham, J.M., Callaway, R.M., 2006. Disturbance facilitates invasion: the effects are stronger abroad than at home. Am. Nat. $168,144-156$.

Hijmans, R.J., Cameron, S.E., Parra, J.L., Jones, P.G., Jarvis, A., 2005. Very high resolution interpolated climate surfaces for global land areas. Int. J. Climatol. 25, 1965-1978.

Joshi, J., Vrieling, K., 2005. The enemy release and EICA hypothesis revisited: incorporating the fundamental difference between specialist and generalist herbivores. Ecol. Lett. 8, 704-714.

Kasim, N.A., Whitehouse, M., Ramachandran, C., Bermejo, M., Lennernäs, H., Hussain, A.S., Junginger, H.E., Stavchansky, S.A., Midha, K.K., Shah, V.P., Amidon, G.L., 2003. Molecular properties of who essential drugs and provisional biopharmaceutical classification. Mol. Pharm. 1, 85-96.

Kaya, Z., Orcan, N., Binzet, R., 2010. Morphological, anatomical and palynological study of Centaurea calcitrapa 1. ssp. cilicica (Boiss. \&Bal.) Wagenitz and Centaurea solstitialis l. ssp. carneola (Boiss.) Wagenitz endemic for Turkey. Pak. J. Bot. 42, 59-69.

Keane, R.M., Crawley, M.J., 2002. Exotic plant invasions and the enemy release hypothesis. Trends Ecol. Evol. 17, 164-170.

Kelsey, R.G., Locken, L.J., 1987. Phytotoxic properties of Cnicin, a sesquiterpene lactone from Centaurea maculosa (spotted knapweed). J. Chem. Ecol. 13, 19-33.

Landau, I., Müller-Schärer, H., Ward, P.I., 1994. Influence of cnicin, a sesquiterpene lactone of Centaurea maculosa (Asteraceae), on specialist and generalist insect herbivores. J. Chem. Ecol. 20, 929-942.

Lange, B.M., Turner, G.W., 2012. Terpenoid biosynthesis in trichomes - current status and future opportunities. Plant Biotechnol. J. 0, 1-21.

Lin, S., Binder, B.F., Hart, E.R., 1998. Insect feeding stimulants from the leaf surface of Populus. J. Chem. Ecol. 24, 1781-1790.

Locken, L.J., Kelsey, R.G., 1987. Cnicin concentrations in Centaurea maculosa, spotted knapweed. Biochem. Syst. Ecol. 15, 313-320.

Majdi, M., Liu, Q., Karimzadeh, G., Malboobi, M.A., Beekwilder, J., Cankar, K., de Vos, R., Todorovice, S., Simonovic, A., Bouwmeester, H., 2011. Biosynthesis and localization of parthenolide in glandular trichomes of feverfew (Tanacetum parthenium L. Schulz Bip.). Phytochemistry 72, $1739-1750$.

Memmott, J., Fowler, S.V., Paynter, Q., Sheppard, A.W., Syrett, P., 2000. The invertebrate fauna on broom, Cytisus scoparius, in two native and two exotic habitats. Acta Oecol 21, 213-222.

Merrill, G.B., Stevens, K.L., 1985. Sesquiterpene lactones from Centaurea solstitialis. Phytochemistry 24, 2013-2018.

Mohammadian, M.A., Watling, J.R., Hill, R.S., 2007. The impact of epicuticular wax on gas-exchange and photoinhibition in Leucadendron lanigerum (Proteaceae). Acta Oecol 31, 93-101.

Montesinos, D., Santiago, G., Callaway, R.M., 2012. Neo-allopatry and rapid reproductive isolation. Am. Nat. 180, 529-533.

Muir, A.D., Majak, W., 1983. Allelopathic potential of diffuse knapweed (Centaurea diffusa) extracts. Can. J. Plant Sci. 63, 989-996.

Müller, C., Riederer, M., 2005. Plant surface properties in chemical ecology. J. Chem. Ecol. 31, 2621-2651.

Müller-Schärer, H., Schaffner, U., Steinger, T., 2004. Evolution in invasive plants: implications for biological control. Trends Ecol. Evol. 19, 417-422.

NIST Atomic Spectra Database, 2012. National Institute of Standards and Technology. Gaithersburg, USA.

Picman, A.K., 1986. Biological activities of sesquiterpene lactones. Biochem. Syst. Ecol. 14, 255-281.

Qin, B., Lau, J.A., Kopshever, J., Callaway, R.M., McGray, H., Perry, L.G., Weir, T.L., Paschke, M.W., Hierro, J.L., Yoder, J., Vivanco, J.M., Strauss, S., 2007. No evidence for root-mediated allelopathy in Centaurea solstitialis, a species in a commonly allelopathic genus. Biol. Invasions 9 , $897-907$. 
Rausher, M.D., 2001. Co-evolution and plant resistance to natural enemies. Nature 411, 857-864.

Ridenour, W.M., Vivanco, J.M., Feng, Y., Horiuchi, J., Callaway, R.M., 2008. No evidence for trade-offs: Centaurea plants from America are better competitors and defenders. Ecol. Monogr. 78, 369-386.

Robinson, S.A., Lovelock, C.E., Osmond, C.B., 1993. Wax as a mechanism for protection against photoinhibition: a study of Cotyledon orbiculata. Bot. Acta 106, 307-312.

Seaman, F.C., 1982. Sesquiterpene lactones as taxonomic characters in the Asteraceae. Bot. Rev. 48, 121-595.

Stevens, K.L., Riopeue, R.J., Wong, R.Y., 1990. Repin, a sesquiterpene lactone from Acroptilon repens possessing exceptional biological activity. J. Nat. Prod. 53 , $218-221$.

Wagner, G.J., Wang, E., Shepherd, R.W., 2004. New approaches for studying and exploiting an old protuberance, the plant trichome. Ann. Bot. 93, 3-11. 